\title{
OPEN Salt-tolerance screening in Limonium sinuatum varieties with different flower colors
}

\begin{abstract}
Xiaojing Xu, Yingli Zhou, Ping Mi, Baoshan Wang ${ }^{\varpi}$ \&ang Yuan ${ }^{\bowtie}$
Limonium sinuatum, a member of Plumbaginaceae commonly known as sea lavender, is widely used as dried flower. Five $L$. sinuatum varieties with different flower colors (White, Blue, Pink, Yellow, and Purple) are found in saline regions and are widely cultivated in gardens. In the current study, we evaluated the salt tolerance of these varieties under $250 \mathrm{mmol} / \mathrm{L} \mathrm{NaCl}$ (salt-tolerance threshold) treatment to identify the optimal variety suitable for planting in saline lands. After the measurement of the fresh weight (FW), dry weight (DW), contents of $\mathrm{Na}^{+}, \mathrm{K}^{+}, \mathrm{Ca}^{2+}, \mathrm{Cl}^{-}$, malondialdehyde (MDA), proline, soluble sugars, hydrogen peroxide $\left(\mathrm{H}_{2} \mathrm{O}_{2}\right)$, relative water content, chlorophyll contents, net photosynthetic rate, and osmotic potential of whole plants, the salt-tolerance ability from strongest to weakest is identified as Pink, Yellow, Purple, White, and Blue. Photosynthetic rate was the most reliable and positive indicator of salt tolerance. The density of salt glands showed the greatest increase in Pink under $\mathrm{NaCl}$ treatment, indicating that Pink adapts to high-salt levels by enhancing salt gland formation. These results provide a theoretical basis for the large-scale planting of $L$. sinuatum in saline soils in the future.
\end{abstract}

Limonium sinuatum L., a native Mediterranean plant, is widely distributed in Northern Africa, western Asia, and Europe ${ }^{1}$. L. sinuatum, a member of the Plumbaginaceae family, is a typical recretohalophyte that can grow in saline ${ }^{2}$ or drought environments due to the presence of salt glands in the epidermis and the surrounding thick cuticle to reduce the water evaporation ${ }^{3}$. Different $L$. sinuatum varieties are usually identified based on flower color. The flower petals are white, while the calyxes can be different colored (e.g., white, blue, pink, yellow, and purple $)^{4}$. The calyxes remain long after the petals have disappeared, making the flowers attractive for long periods of time and excellent for use as fresh cut flowers or in dried arrangements ${ }^{5}$. The flower stems are approximately 40-50 cm tall, each flower stem has 2-3 branches with 5-6 flowers clustered together, and the diameter of each flower is $\sim 0.5 \mathrm{~cm}^{6}$. L. sinuatum is commonly referred to as statice, sea lavender, sea notchleaf ${ }^{7}$, or wavyleaf sea lavender when used for gardening or floral arrangements ${ }^{7}$. Moreover, the entire plant is used as a traditional Chinese medicine for hemostasis ${ }^{8}$. In China, L. sinuatum is widely distributed along the coast of the Yellow Sea and the Bohai Sea .

Soil salinization is a major environmental factor affecting plant growth and development ${ }^{10}$. Plant salt tolerance is a highly complex trait involving many factors, such as tissue and organ structure and physiological and biochemical reactions ${ }^{11}$. Salt stress alters the contents of soluble sugars, ions, and proline in plants ${ }^{12}$, and it affects the synthesis of plant soluble substances ${ }^{13}$, leading to changes in salt tolerance ${ }^{14}$.

Most crops are non-halophytes, and their growth is inhibited in saline soil ${ }^{15}$. By contrast, halophytes, including euhalophytes, recretohalophytes, and psudohalophytes ${ }^{16}$, can grow and complete their lifecycles in the presence of $\geq 200 \mathrm{mmol} / \mathrm{L} \mathrm{NaCl}^{17}$. L. sinuatum is a recretohalophyte with salt glands for excreting excess $\mathrm{Na}^{+}$out of the plants to avoid salt stress. To date, 67 species with salt glands have been reported, belonging to 13 families $^{18}$. Among Plumbaginaceae family members, many studies have been carried out on L. bicolor, including salt secretion measurements ${ }^{19}$, analysis of salt gland differentiation ${ }^{20}$, and transcriptomic analysis during leaf development and in response to $\mathrm{NaCl}$ treatment ${ }^{16}$. However, although L. sinuatum also belongs to Limonium, few studies of the salt resistance in different varieties of this plant have been reported.

Generally, L. sinuatum has greater potential than L. bicolor for use as a horticultural crop in saline soils ${ }^{20}$, because the growth cycle of $L$. sinuatum is short (do not need vernalization for flowering) and the flower color is various, and it is more suitable for gardening ${ }^{21}$. Given that Limonium species are considered to be pioneer plants for transforming saline soils ${ }^{22}$, it is important to explore the use of these plants to maximize the utilization of saline lands to increase the economic and ecological value of these environments. Here, we selected five common 
garden varieties of L. bicolor (named based on flower color), including White, Blue, Pink, Yellow, and Purple, and determined their salt-tolerance thresholds. We evaluated the salt tolerance of these varieties by comparing fresh weight, dry weight, ion, proline, soluble sugars, and chlorophyll content, net photosynthetic rate, and osmotic potential to identify the varieties with the strongest salt tolerance. Based on these salt-tolerance indicators, we identified the most suitable variety for planting in saline soil.

\section{Materials and methods}

Plant materials and growth conditions. The seeds of five Limonium sinuatum varieties with different flower colors (White, Blue, Pink, Yellow, and Purple) were purchased from Lanxiang Horticulture Seedling Co., Ltd. (China). This study complies with local and national regulations. The author Baoshan Wang had formally identified L. sinuatum, and the seeds harvesting process is in full compliance with relevant government guidelines. Unfortunately, we were unable to find a voucher specimen of L. sinuatum stored in any publicly available herbarium. The dried seeds were stored in a refrigerator at $<4{ }^{\circ} \mathrm{C}$. The seeds were sterilized in $6 \% \mathrm{NaClO}$ for $15 \mathrm{~min}$, washed with sterile distilled water, and sown in nutrient soil (soil: vermiculite: perlite, $3: 1: 1$ ). The plants were grown in a growth chamber at $28{ }^{\circ} \mathrm{C} / 23{ }^{\circ} \mathrm{C}$ (day/night) under $600 \mu \mathrm{mol} / \mathrm{m}^{2} / \mathrm{s}$ full-spectrum light $(15 \mathrm{~h}$ photoperiod) and $60 \%$ relative humidity. In order to make accurate comparisons among the five varieties, all plants were cultured for six months under the above conditions for flowering (Fig. 1). Flower color can be used to distinguish among different varieties of L. sinuatum, including White, Blue, Pink, Yellow, and Purple.

Measurement of salt-tolerance threshold. To determine the salt-tolerance threshold, two-week-old seedlings with two expanded leaves were treated with different concentrations of $\mathrm{NaCl}(0,100,200,300$ and $400 \mathrm{mmol} / \mathrm{L}$ ). After two weeks of treatment, the aerial parts of the plants were collected and used to measure fresh weight (FW) and dry weight (DW) according to Huang et al. ${ }^{23}$. Five replicates were performed per variety, and the means among different varieties under each $\mathrm{NaCl}$ treatment were used to calculate the salt-tolerance threshold. In detail, a fit regression curve was established with different $\mathrm{NaCl}$ concentrations $v s$. FW or DW. The $\mathrm{NaCl}$ concentration at which the plants showed $50 \% \mathrm{FW}$ or $\mathrm{DW}^{24}$ compared to the non-NaCl treatment group was considered to be the salt-tolerance threshold.

After the determination of salt-tolerance threshold, two-week-old seedlings of the five varieties with two expanded leaves were then re-treated with $0 \mathrm{mmol} / \mathrm{L}$ and $250 \mathrm{mmol} / \mathrm{L} \mathrm{NaCl}$ (considered to be the salt-tolerance threshold in the following experiments) for two weeks and used to measure the physiological indicators.

Determination of physiological indicators. Determination of $F W, D W$ and relative water content of leaf.. After cleaning the leaves with $10 \mathrm{mM}$ calcium chloride solution ${ }^{25}$ followed by deionized water, $\mathrm{FW}$ of the leaves was measured immediately and DW was obtained following incubation at $105^{\circ} \mathrm{C}$ for 15 min and drying to constant weight at $70^{\circ} \mathrm{C}$ for 2 days $s^{23}$. Five replicates were performed per variety and treatment. The reduction rate was calculated as (FW under control condition-FW under saline condition)/FW under control condition $\times 100 \%$. The same method was processed in calculating the reduction rate of DW. The relative water content is calculated as $(\mathrm{FW}-\mathrm{DW}) / \mathrm{FW} \times 100 \%{ }^{26}$.

Determination of sodium ion $\left(\mathrm{Na}^{+}\right)$, potassium ion $\left(\mathrm{K}^{+}\right)$, calcium ion $\left(\mathrm{Ca}^{2+}\right)$, and chloride ion $\left(\mathrm{Cl}^{-}\right)$contents.. The ion contents in the samples were measured according to Higinbotham ${ }^{27}$. In brief, leaf tissue $(0.5 \mathrm{~g} \mathrm{FW})$ was collected from plants under both 0 and $250 \mathrm{mmol} / \mathrm{L} \mathrm{NaCl}$ treatment for all five varieties. The tissues were ashed, dissolved in $\mathrm{HNO}_{3}$, and the contents of $\mathrm{Na}^{+}, \mathrm{K}^{+}$, and $\mathrm{Ca}^{2+}$ measured using a Flame photometer (FP6440, Yuanxi, Shanghai, China). $\mathrm{Cl}^{-}$content was measured by ion chromatography according to Wang ${ }^{28}$. Briefly, after boiling for $30 \mathrm{~min}$ and filtering through a $0.22 \mu \mathrm{m}$ filter membrane, the ion solution was injected into an ion chromatograph (ICS-90A, ThermoFisher, Massachusetts, USA) to measure $\mathrm{Cl}^{-}$contents. The ion concentration is shown as $\mathrm{mmol} / \mathrm{g}$ FW. Five replicates were performed for each variety and treatment. Given that $\mathrm{Na}^{+}$content increased under $\mathrm{NaCl}$ treatment, the increase rate was calculated as $\left(\mathrm{Na}^{+}\right.$content under saline condition $-\mathrm{Na}^{+}$content of control) $/ \mathrm{Na}^{+}$content of control $\times 100 \%$. The same calculation method was applied in the increase rate of $\mathrm{Cl}^{-}$.

Determination of proline content, osmotic potential, malondialdehyde (MDA), hydrogen peroxide $\left(\mathrm{H}_{2} \mathrm{O}_{2}\right)$, soluble sugars, and chlorophyll content, and photosynthetic rate.. Proline content was determined in accordance with Demiral $^{29}$. The plant tissue was ground, and ground tissue $(0.5 \mathrm{~g} \mathrm{FW})$ was added to $10 \mathrm{~mL}$ of $5 \%$ acetic acid and $40 \mathrm{~mL}$ of distilled water. After filtering, the filtrate $(8 \mathrm{~mL})$ was mixed with $0.8 \mathrm{~g}$ zeolite with shaking for $5 \mathrm{~min}$ and centrifuged for $10 \mathrm{~min}(1500 \mathrm{~g})$. The supernatant $(3 \mathrm{~mL})$ was combined with glacial acetic acid $(3 \mathrm{~mL})$ and ninhydrin reagent $(3 \mathrm{~mL})$ and boiled for $1 \mathrm{~h}$. Benzene $(3 \mathrm{~mL})$ was used for static layering, and the upper colored liquid was collected and used to measure optical density at $515 \mathrm{~nm}$. The proline content was calculated from a standard curve based on the optical density. Five replicates were performed for each variety and treatment.

The osmotic potential was measured as described by Tomlinson ${ }^{30}$. Fresh leaf tissue $(0.5 \mathrm{~g})$ was cut into small pieces, frozen in liquid nitrogen, and placed into a syringe to squeeze out and collect the cell sap. A freezing point osmometer (SMC 30C-1, Tianhe, Tianjin, China) was used to measure the osmotic potential of the plant cell sap. The formula used to calculate osmotic potential is $-\mathrm{iCRT}\left(\mathrm{R}=0.0083143 \mathrm{~L} \mathrm{Mpa} \mathrm{Mol}^{-1} \mathrm{~K}^{-1}, \mathrm{~T}=298 \mathrm{~K}\right)$. Five replicates were performed for each variety and treatment.

The MDA content was determined as reported in Hong ${ }^{31}$. Leaf tissue $(0.5 \mathrm{~g})$ was collected and homogenized in $5 \mathrm{~mL} 0.1 \%$ TCA. The homogenate was transferred to the test tube, combined with $5 \mathrm{~mL} 0.5 \%$ thiobarbituric acid solution, and boiled for $10 \mathrm{~min}$. The sample was centrifuged at $1500 \mathrm{~g}$ for $15 \mathrm{~min}$, and the optical density of the supernatant was measured at $532 \mathrm{~nm}$ and $600 \mathrm{~nm}$. MDA content $(\mathrm{mmol} / \mathrm{g} \mathrm{FW})=\Delta \mathrm{AN} / 155 \mathrm{~W}, \Delta \mathrm{A}$ is the difference between $\mathrm{A}_{532}$ and $\mathrm{A}_{600} ; \mathrm{N}$ is the total volume of the supernatant; 155 is the absorption coefficient of 


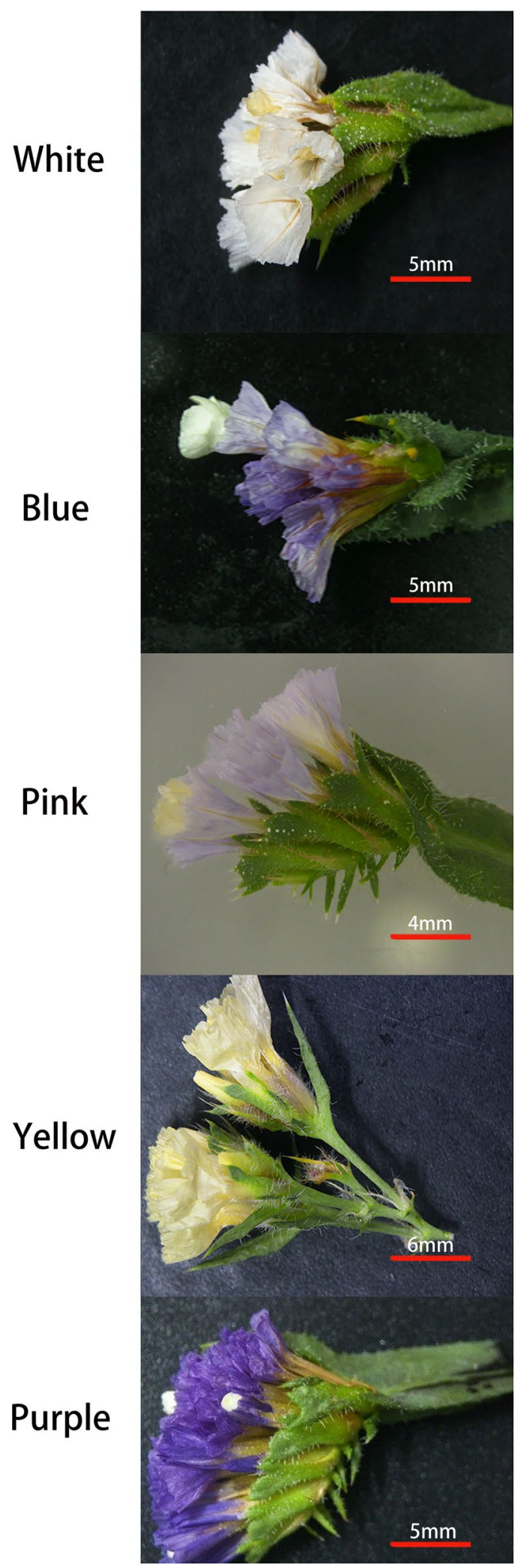

Figure 1. Flower color in different varieties of Limonium sinuatum after 6 months of growth. The photographs show flowers from the White, Blue, Pink, Yellow, and Purple varieties. Different colors indicates the calyx's colors.

$1 \mathrm{mmol}$ reaction product at $532 \mathrm{~nm}$; W is the fresh weight of the plant material (g). Five replicates were performed for each variety and treatment.

The content of $\mathrm{H}_{2} \mathrm{O}_{2}$ was determined as described by Vergara ${ }^{32}$. In brief, fresh leaves $(0.3 \mathrm{~g})$ was grinded in $5 \mathrm{~mL}$ precooled acetone before centrifuged at $500 \mathrm{~g}$ for $8 \mathrm{~min}$. Afterward the supernatant $(1 \mathrm{~mL})$ was mixed with 
(a)

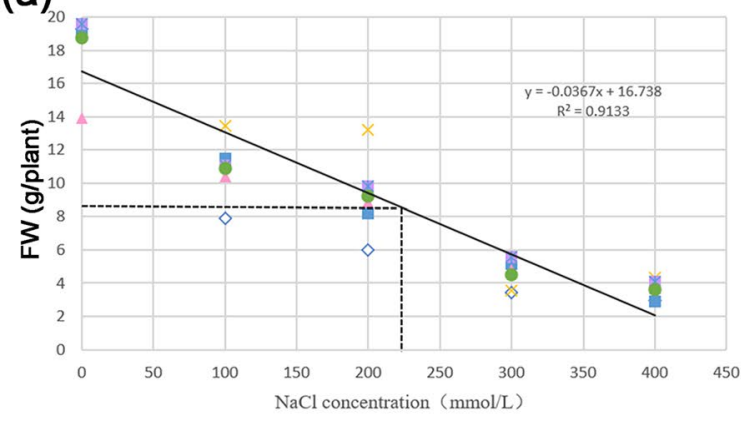

(b)

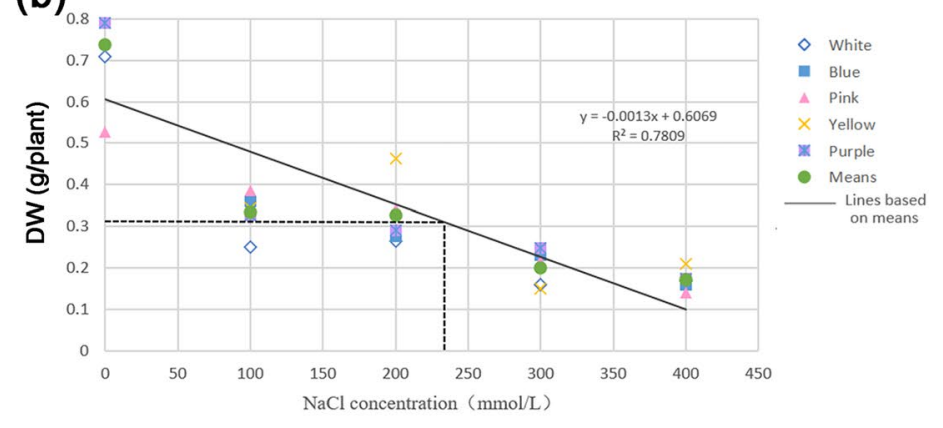

Figure 2. Salt-tolerance thresholds of five varieties of Limonium sinuatum. A 50\% reduction in biomass compared to the control was used as the standard to determine the salt-tolerance threshold. (a) Changes in fresh weight (FW) of the leaves of five L. sinuatum varieties under different salt treatments. (b) Changes in dry weight (DW) of the leaves of five L. sinuatum varieties under different salt treatments.

ammonia $(0.2 \mathrm{~mL})$ and $20 \% \mathrm{TiCl}_{4}(0.1 \mathrm{~mL})$ for $2 \mathrm{~min}$, the precipitate was washed with acetone for 3-5 times and dissolved in $2 \mathrm{M} \mathrm{H}_{2} \mathrm{SO}_{4}(5 \mathrm{~mL})$ after centrifuged at $600 \mathrm{~g}$ for $7 \mathrm{~min}$. Then the content of $\mathrm{H}_{2} \mathrm{O}_{2}$ was measured at $415 \mathrm{~nm}$ and calculated as $\mathrm{H}_{2} \mathrm{O}_{2}$ content $(\mu \mathrm{mol} / \mathrm{g} \mathrm{FW})=\mathrm{CV}_{\mathrm{T}} / \mathrm{FWV}_{1}$, C is the concentration of $\mathrm{H}_{2} \mathrm{O}_{2}$ in the sample checked on the standard curve $(\mu \mathrm{mol}), \mathrm{V}_{\mathrm{T}}$ was the total volume of sample extract $(\mathrm{mL}), \mathrm{V}_{1}$ was the volume of sample extract $(\mathrm{mL})$, and FW was the fresh weight of plant tissue $(\mathrm{g})$. Five replicates were performed for each variety and treatment.

Soluble sugars were measured following the protocol of Prado ${ }^{33}$. Fresh leaf tissue $(0.3 \mathrm{~g})$ was dissolved in $10 \mathrm{~mL}$ of double distilled $\mathrm{H}_{2} \mathrm{O}\left(\mathrm{ddH}_{2} \mathrm{O}\right)$ in a boiling water bath for $50 \mathrm{~min}$, filtered, and brought to a volume of $25 \mathrm{~mL}$. Afterward $0.5 \mathrm{~mL}$ of extract solution was combined with $1.5 \mathrm{~mL}$ distilled water, $0.5 \mathrm{~mL}$ ethyl anthrone acetate, and $5 \mathrm{~mL}$ concentrated sulfuric acid, shaken thoroughly, boiled in water bath for $1 \mathrm{~min}$, and cooled. The optical density of the solution was measured at $630 \mathrm{~nm}$. The soluble sugars content was calculated from a standard curve. Five replicates were performed for each variety and treatment.

Chlorophyll levels were determined referring to Maxwell ${ }^{34}$. Leaf tissue $(0.3 \mathrm{~g})$ was combined with $5 \mathrm{~mL}$ dimethyl sulfoxide in $5 \mathrm{~mL} 80 \%$ acetone and incubated in a $65^{\circ} \mathrm{C}$ water bath at $24 \mathrm{~h}$ (protected from the light) to fully decolorize. Afterward bring to $25 \mathrm{~mL}$ after filtration and the solution was used to measure the optical density at $663 \mathrm{~nm}, 645 \mathrm{~nm}$, and $470 \mathrm{~nm}$. Chlorophyll content $\left(\mathrm{mg} \mathrm{g}^{-1}\right.$ or $\left.\mathrm{mg} \mathrm{dm}^{-2}\right)=\mathrm{CV} / 1000 \mathrm{~A}, \mathrm{C}$ is chlorophyll concentration ( $\mathrm{mg} \mathrm{L}^{-1}$ or $\left.\mathrm{mg} \mathrm{dm}^{-2}\right)$; $\mathrm{V}$ is the total volume of extract solution $(\mathrm{mL})$; $\mathrm{A}$ is fresh weight of the sample $(\mathrm{g})$ or sampling area $\left(\mathrm{dm}^{-2}\right)$. The pigment concentration $(\mathrm{mg} / \mathrm{L})$ was calculated as $\mathrm{C}_{a}=12.7 \mathrm{~A}_{663}-2.69 \mathrm{~A}_{645}$; $\mathrm{C}_{b}=22.9 \mathrm{~A}_{645}-4.68 \mathrm{~A}_{663} ; \mathrm{C}_{\text {total }}=20.0 \mathrm{~A}_{645}+8.02 \mathrm{~A}_{663} ; \mathrm{C}_{\mathrm{XC}}=\left(1000 \mathrm{~A}_{470}-3.27 \mathrm{C}_{a}-104 \mathrm{C}_{b}\right) / 229 ; \mathrm{C}_{a}, \mathrm{C}_{b}$ are the concentrations of chlorophyll $a$ and $b, \mathrm{C}_{\text {total }}$ is the concentration of total chlorophyll; $\mathrm{C}_{\mathrm{XC}}$ is the total concentration of carotenoids. Five replicates were performed for each variety and treatment.

The photosynthetic rate was measured on the basis of Wang ${ }^{35}$. In this experiment, a photosynthetic instrument (LI-6400XT, LI-COR, Nebraska, USA) was used to measure the photosynthetic parameters of leaves. The photosynthetic effective quantum density, $\mathrm{U}_{\mathrm{PAR}}\left(\mu \mathrm{mol} \mathrm{m} \mathrm{m}^{-1} \mathrm{~s}^{-1}\right), \mu$ is $4.55^{36}$, was measured at a temperature of $23^{\circ} \mathrm{C}$, and the leaf area of each cultivar was $1 \mathrm{~cm}^{2}$. Five replicates were performed for each variety and treatment.

Determination of salt gland density in different varieties. The density of salt glands was measured according to Yuan ${ }^{37}$. The leaves were fixed in a mixture of ethanol and acetic acid $(3: 1 ; \mathrm{v} / \mathrm{v})$, rinsed with $70 \%$ ethanol to decolorize, and cleared in Hoyer's solution. Afterward cleaned leaves were fixed on a glass slide for DIC microscopy (ECLIPSE 80i, Nikon, Tokyo, Japan). The salt gland density was calculated according to Ding ${ }^{38}$ and expressed as number per $\mathrm{mm}^{2}$. Five replicates were performed for each variety and treatment.

\section{Data analysis}

Statistical analysis and correlation were performed using SPSS 13.0 software (SPSS Software Inc., USA). The results were subjected to a one-way analysis of variance (ANOVA), and Duncan's test was used to determine significant differences between the means $(P=0.05)$. In the figures, the error bars represent the means \pm standard deviations $(n=5)$ and different letters indicate significant differences at $P=0.05$. Correlation is processed at $P=0.05$ and 0.01 using Pearson correlation analysis. The figures were generated using SigmaPlot 12.5 (Systat Software, Chicago, IL, USA).

\section{Results}

Identification of the salt-tolerance threshold. Plant biomass is an important measure of salt tolerance. Figure 2 shows the biomass of the aerial parts of plants under a gradient of different $\mathrm{NaCl}$ concentrations $(0,100,200,300$, and $400 \mathrm{mmol} / \mathrm{L})$ after 2 weeks of treatment. FW and DW were measured in the five varieties of $L$. sinuatum seedlings and constructed a regression curve based on the means of five data under different treatments as independent variables. Most studies use the salt concentration at which plant growth or biomass decreases by $50 \%$ of the control value as the salt-tolerance threshold ${ }^{39}$. Here, when the FW and DW of the 


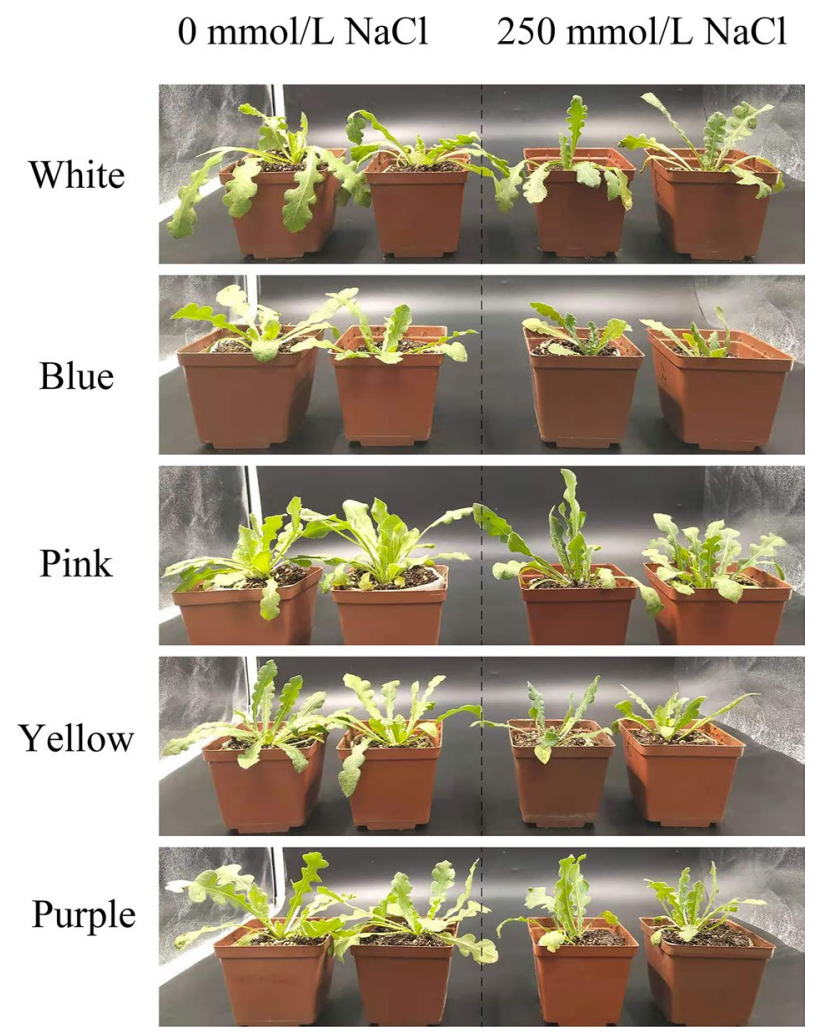

Figure 3. Growth of five varieties of Limonium sinuatum seedlings after two weeks of salt treatment.

upper parts of the seedlings were reduced by $50 \%$ of the non- $\mathrm{NaCl}$ treatment value, different varieties showed different salt-tolerance thresholds. The highest threshold was obtained for Pink ( $250 \mathrm{mmol} / \mathrm{L})$ (Supplementary Fig. 1), suggesting that Pink is the most salt-tolerant variety. To identify the optimal salt concentration for further experiments, we calculated the average salt-tolerance threshold, i.e., $228 \mathrm{mmol} / \mathrm{L}$ for $\mathrm{FW}$ and $233 \mathrm{mmol} / \mathrm{L}$ for DW (Fig. 2). Therefore, a salt-tolerance threshold of $250 \mathrm{mmol} / \mathrm{L}$ was utilized in subsequent experiments.

Pink shows the best growth under $250 \mathrm{mmol} / \mathrm{L} \mathrm{NaCl}$ treatment. All varieties showed inhibited growth under $250 \mathrm{mmol} / \mathrm{L} \mathrm{NaCl}$ treatment (Fig. 3), but the changes in FW and DW showed no significant trends among varieties (Supplementary Fig. 2). In order to make effective comparison among different varieties, FW and DW reduction rate are calculated to compare the changes between control and saline condition (Fig. 4). Pink showed the least FW reduction, followed by Yellow, Purple, White and Blue, while White has the least DW reduction, afterward Pink, Yellow, Purple and Blue. Based on the reduction rate of FW and DW, Pink is considered the most salt tolerance variety, followed by Yellow, Purple, White, and Blue. Biomass can be used as a measure of plant growth, and various physiological processes could be responsible for the ability of Pink to maintain growth in the presence of salt. Therefore, we measured the physiological indicators of the different varieties under $\mathrm{NaCl}$ treatment in order to reveal the underlying salt-tolerance mechanisms.

Effect of $\mathrm{NaCl}$ treatment on different physiological indicators in five varieties. Comparisons of the $\mathrm{Na}^{+}, \mathrm{K}^{+}, \mathrm{Ca}^{2+}$, and $\mathrm{Cl}^{-}$contents; MDA, soluble sugars, proline contents, $\mathrm{H}_{2} \mathrm{O}_{2}$ content and relative water content of leaf; chlorophyll contents; and osmotic potential and photosynthetic rate are shown in Figs. 5, 6, 7 and 8 , respectively. Each variety showed significant changes under $\mathrm{NaCl}$ treatment.

Figure 5 shows a comparison of the relative $\mathrm{Na}^{+}, \mathrm{K}^{+}, \mathrm{Ca}^{2+}$ and $\mathrm{Cl}^{-}$contents among varieties under $250 \mathrm{mmol} / \mathrm{L}$ $\mathrm{NaCl}$ treatment. $\mathrm{Na}^{+}$and $\mathrm{Cl}^{-}$content under $\mathrm{NaCl}$ treatment increased compared with the control in all varieties (Fig. 5a,c), while $\mathrm{K}^{+}$and $\mathrm{Ca}^{2+}$ showed various trends in different varieties (Fig. 5e,f). Given that $\mathrm{Na}^{+}$and $\mathrm{Cl}^{-}$are considered the stress ion to protoplast and different varieties have various basal level under control, the increase rate of $\mathrm{Na}^{+}$(Fig. 5b) and $\mathrm{Cl}^{-}$(Fig. 5d) under $\mathrm{NaCl}$ treatment are calculated in each variety in order to make intuitive comparison among different varieties. Pink shows the least $\mathrm{Na}^{+}$increase (1.87\%) under saline condition, followed by Yellow, Blue, Purple and White. In the aspect of $\mathrm{Cl}^{-}$increase, Purple (96.04\%) has the least, afterward Yellow, Pink, White and Blue. Together with the increase rate of $\mathrm{Na}^{+}$and $\mathrm{Cl}^{-}$, these results indicate that Pink accumulates less $\mathrm{Na}^{+}$and $\mathrm{Cl}^{-}$than the other varieties under high-salt conditions, which should lead to less injury than the other varieties.

Figure 6 shows a comparison of the relative MDA, soluble sugars, proline contents, $\mathrm{H}_{2} \mathrm{O}_{2}$ and relative water content of leaf among varieties. Though the MDA increase rate of Pink under saline condition (Fig. $6 \mathrm{~b}$ ) shows the most, the absolute value of MDA (Fig. 6a) is the least accumulation in Pink, indicating that Pink suffered the 


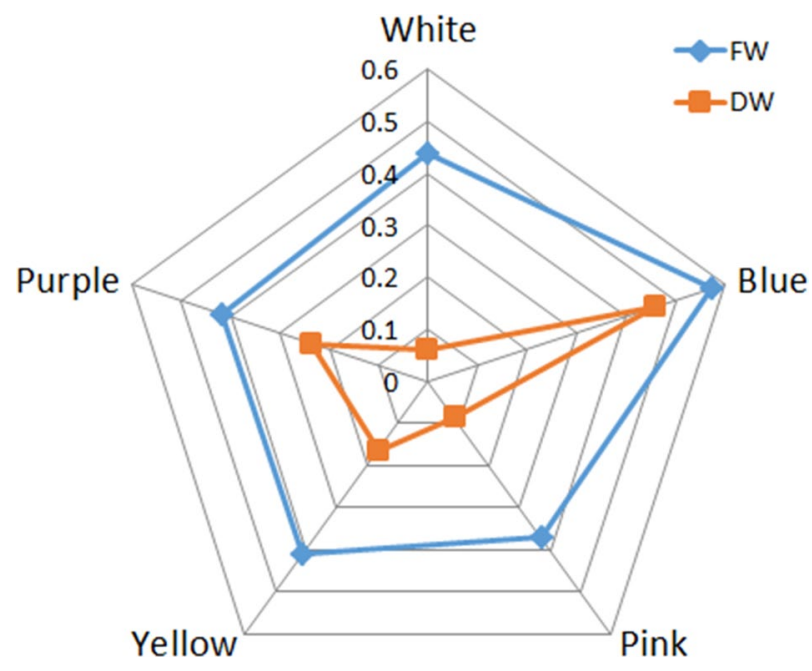

Figure 4. Effect of $\mathrm{NaCl}$ stress on the reduction rate of fresh weight (FW) and dry weight (DW) of the leaves of five Limonium sinuatum varieties. The reduction rate was calculated as (FW or DW under control condition FW or DW under saline condition)/FW or DW under control condition $\times 100 \%$.

least amount of damage under salt treatment, as MDA can be used as a measure of the degree of damage under $\mathrm{NaCl}$ treatment ${ }^{40}$. High accumulation of MDA can be detected in White and Blue (Fig. 6a), which may explain the serious damage level.

To cope with the damage caused by $\mathrm{NaCl}$ treatment, cells usually accumulate organic osmotic regulating substance such as soluble sugars (Fig. 6c) and proline (Fig. 6e). High accumulation of soluble sugars is shown in Pink and Purple, and the increase rate (Fig. 6d) under saline treatment indicates the comparison between varieties. Highest increase rate is detected in Purple, followed by Pink and Yellow. Besides, high proline accumulation is shown in Blue, Yellow and Pink in descending order of actual value (Fig. 6e), while the increase rate has the opposite trend with the most in White, Blue and Pink (Fig. 6f). Proline reduces the osmotic potential in the cell $^{41}$, allowing it to resist external osmotic stress, thereby improving plant survival in adverse environments ${ }^{29}$. Proline content depends on the catabolism of sugar ${ }^{42}$.Combined the absolute value and the increase rate, Pink is considered to accumulate a large amounts of soluble sugars and proline to improve the osmotic adjustment ability under salt treatment. The large accumulation of osmoregulation substances can effectively reduce the osmotic potential under $\mathrm{NaCl}$ treatment ${ }^{43}$. Figure 8 (a) shows that the osmotic potential decline markedly in all varieties, and Yellow and Pink have the most reduction rate (Fig. 8b).

Moreover, $\mathrm{H}_{2} \mathrm{O}_{2}$, as a kind of superoxide, can cause oxidative stress to plants under various stresses ${ }^{44}$. In Fig. 6g, under salt stress, the lowest $\mathrm{H}_{2} \mathrm{O}_{2}$ generation is detected in Pink, while higher in White and Purple, which indicates that Pink suffers the least oxidative stress under salt treatment and is more suitable for saline environment. In addition, relative water content is also measured (Fig. 6h) and no significant difference is detected among different varieties, indicating that all varieties of $L$. sinuatum can keep normal moisture condition to cope with physiological drought of $\mathrm{NaCl}^{45}$.

Plants always produce large amounts of pigments under saline environment to maintain normal photosynthetic efficiency. In addition, a positive correlation was detected between chlorophyll content and net photosynthetic rate ${ }^{46}$. Figure 7 shows a comparison of the relative chlorophyll content among varieties. In order to show the changes in pigment content in more detail, the changes in total chlorophyll, chlorophyll $a$, chlorophyll $b$, and carotenoid contents are shown. The pigment contents of the Pink and Purple varieties were high, which help improve the photosynthetic rate. Under $\mathrm{NaCl}$ treatment, net photosynthetic rate is obviously inhibited in all varieties (Fig. 8c). Pink shows the highest under saline condition, and the reduction rate under salt treatment is also the lowest in Pink (Fig. 8d). These results further explain why Pink has the highest biomass under $\mathrm{NaCl}$ treatment, which may be due to high accumulation in osmoregulation substance and high photosynthetic efficiency.

Effects of $\mathrm{NaCl}$ on salt gland density of five varieties of Limonium sinuatum. Salt glands are structures for salt secretion that are specifically produced by recretohalophytes ${ }^{47}$. We therefore performed statistical analysis of the salt gland densities of expanded leaves of the five L. sinuatum varieties under $\mathrm{NaCl}$ treatment.

Figure 9a shows the changes in salt gland density in the leaves of the five varieties of $L$. sinuatum under salt stress (images shown in Supplementary Fig. 3). Salt gland density increased in all varieties under $\mathrm{NaCl}$ treatment compared to the control. The density of salt glands in Pink increased by $225.86 \%$ (Fig. 9b), while in Purple only $7 \%$. The increased salt gland can help the plants to excrete more $\mathrm{Na}^{+}$outsides in order to further decrease the $\mathrm{Na}^{+}$accumulation in vivo.

Finally, given that Pink showed the greatest tolerance to $\mathrm{NaCl}$ treatment, in order to verify the optimal variety suitable for growing in field, we examined flowering in the five varieties grown in Yellow River Delta (salt content: 0.2\%). After six months of growth, only Pink and Yellow plants flowered consistently, whereas the three other varieties rarely flowered and only showed vegetative growth (Fig. 10). These results suggest that Pink and Yellow 

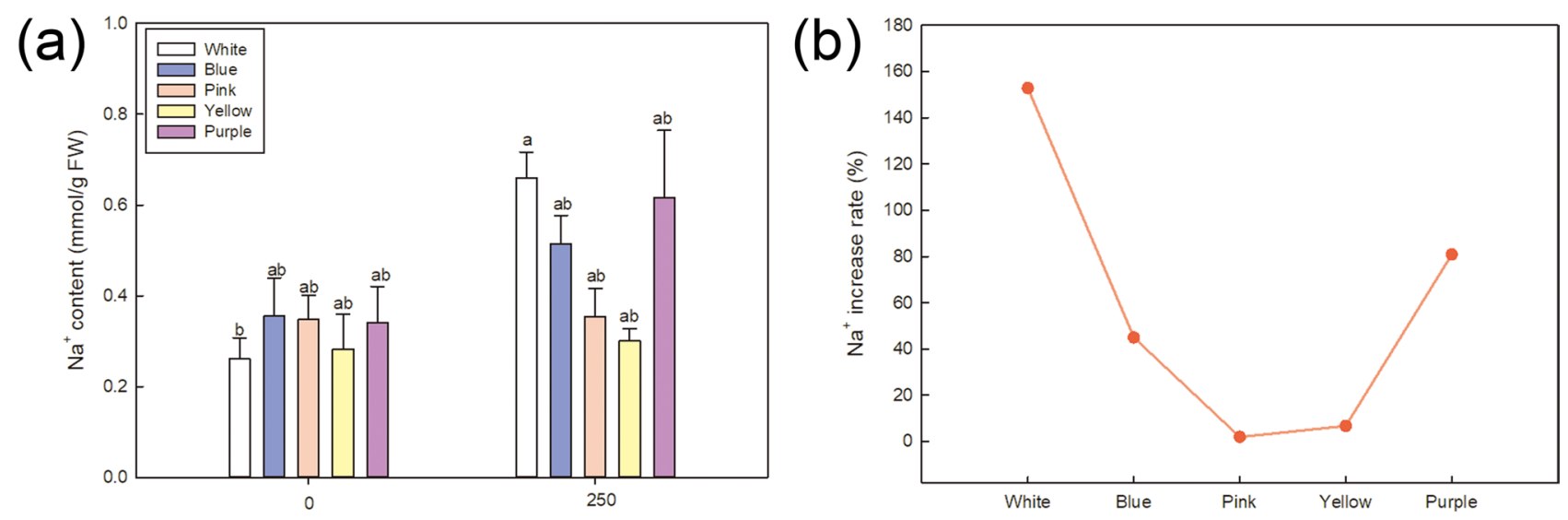

$\mathrm{NaCl}$ concentration $(\mathrm{mmol} / \mathrm{L})$
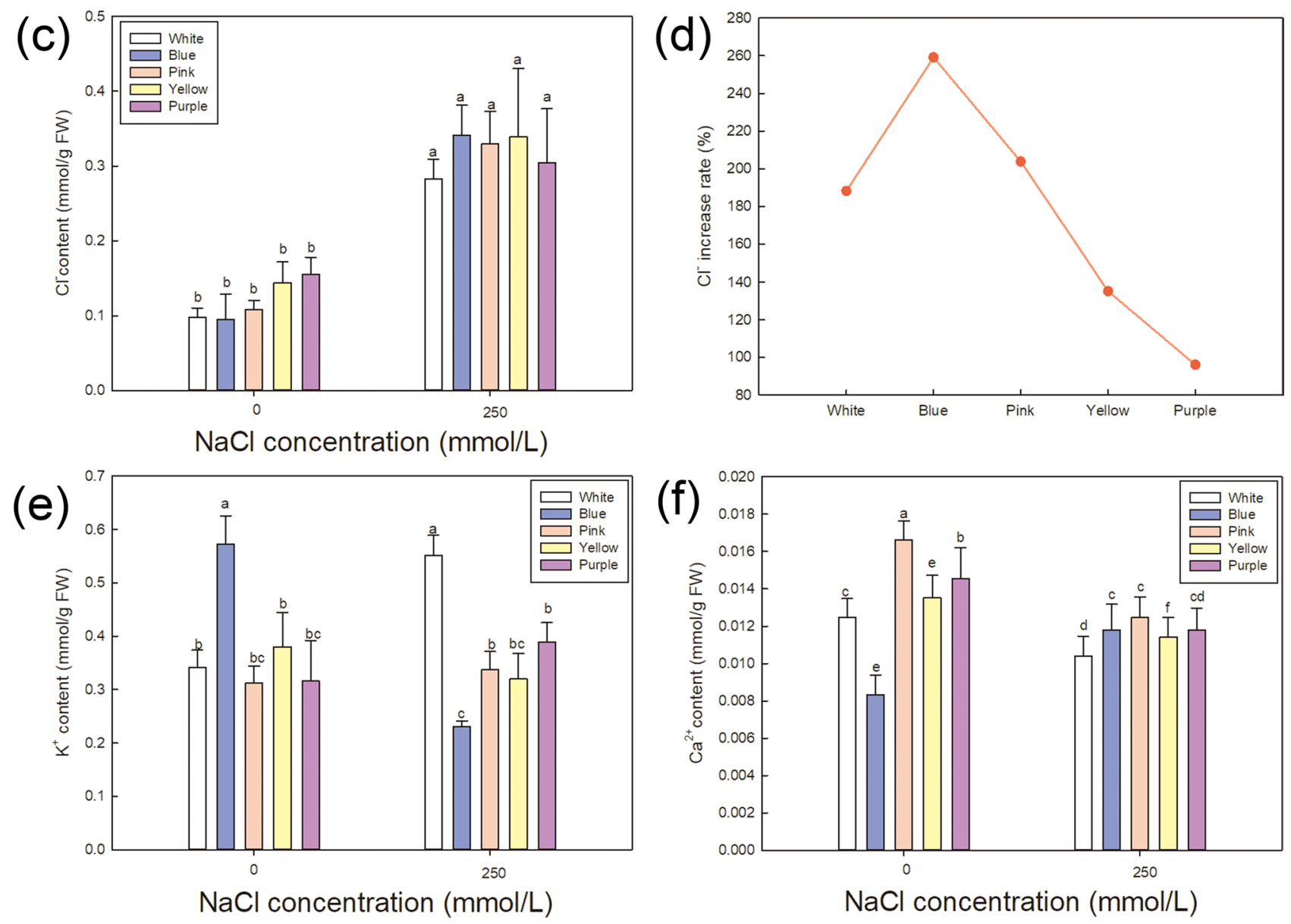

Figure 5. Effect of $\mathrm{NaCl}$ treatment on $\mathrm{Na}^{+}, \mathrm{K}^{+}, \mathrm{Ca}^{2+}$, and $\mathrm{Cl}^{-}$contents. Contents of $\mathrm{Na}^{+}(\mathbf{a}), \mathrm{Cl}^{-}(\mathbf{c}), \mathrm{K}^{+}$(e) and $\mathrm{Ca}^{2+}(\mathbf{f})$ under control and $\mathrm{NaCl}$ treatment in different varieties. The data are means $\pm \mathrm{SD}$ of five replicates.

Different letters indicate significant differences between two groups at $P=0.05$ using Duncan's test with SPSS. (b, d) The increase rate of $\mathrm{Na}^{+}$and $\mathrm{Cl}^{-}$under $\mathrm{NaCl}$ treatment in five varieties, which was calculated as (ion contents under $\mathrm{NaCl}$ treatment-ion contents under control)/ion contents under control $\times 100 \%$.

are the optimal varieties for the development of saline horticulture and further planting in saline soil, which is consistence with the formal results in laboratory conditions.

\section{Discussion}

L. sinuatum is a pioneer plant that could be used for the improvement of saline lands due to the high salt resistance and various colors ${ }^{48}$. Therefore, it is important to identify the best salt-tolerant varieties for cultivation in these areas. In the current study, Pink showed the highest biomass and the strongest salt resistance among the five varieties examined. Our analysis of physiological indicators including $\mathrm{Na}^{+}, \mathrm{K}^{+}, \mathrm{Ca}^{2+}$, and $\mathrm{Cl}^{-}$contents; MDA, soluble sugars, proline contents, $\mathrm{H}_{2} \mathrm{O}_{2}$ content, relative water content and chlorophyll contents, osmotic 
(a)

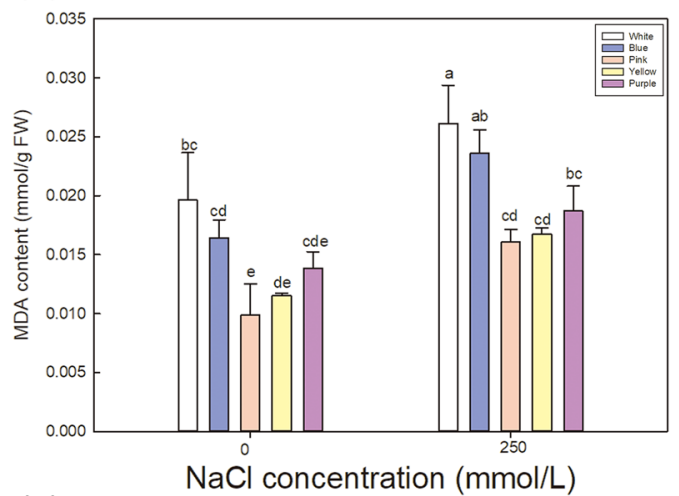

(c)

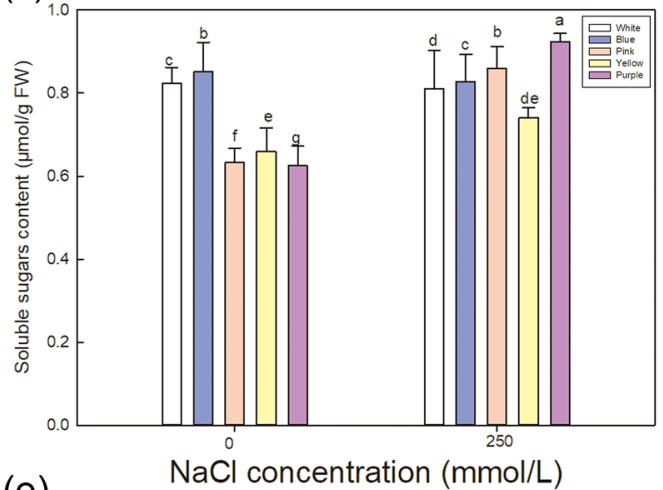

(e)
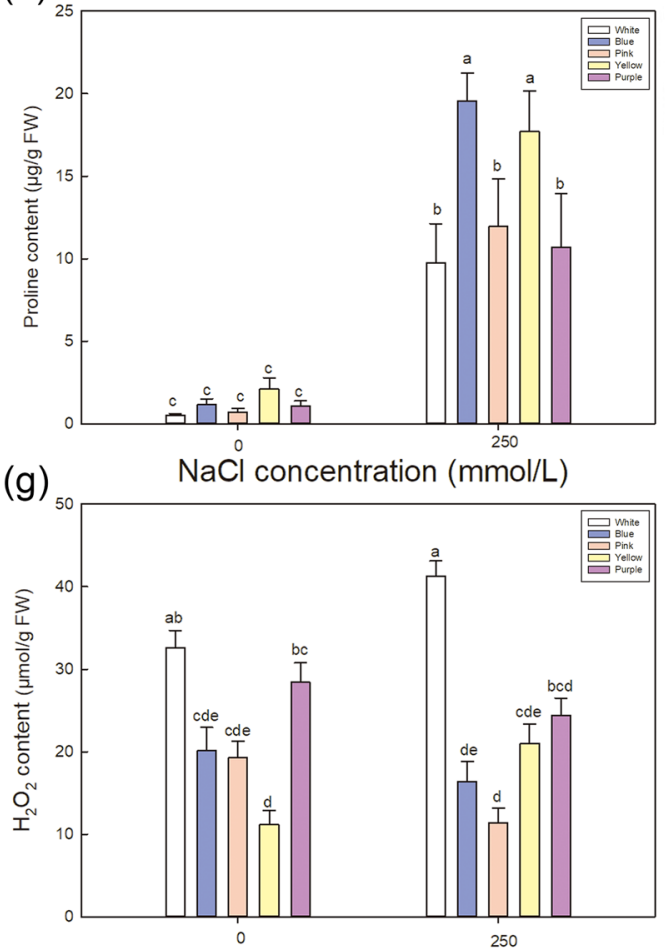

$\mathrm{NaCl}$ concentration (mmol/L) (b)

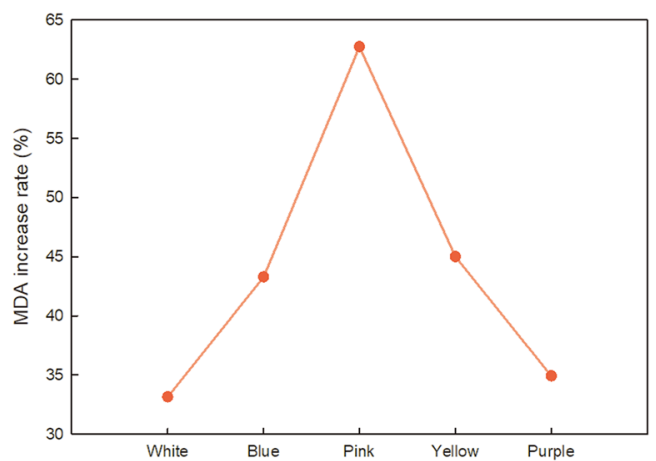

(d)

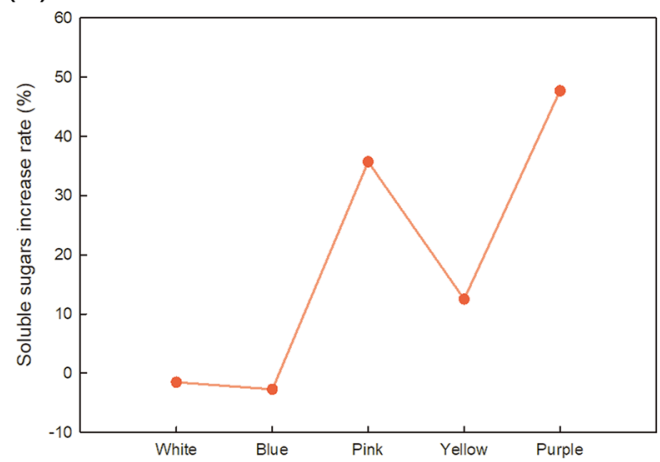

(f)

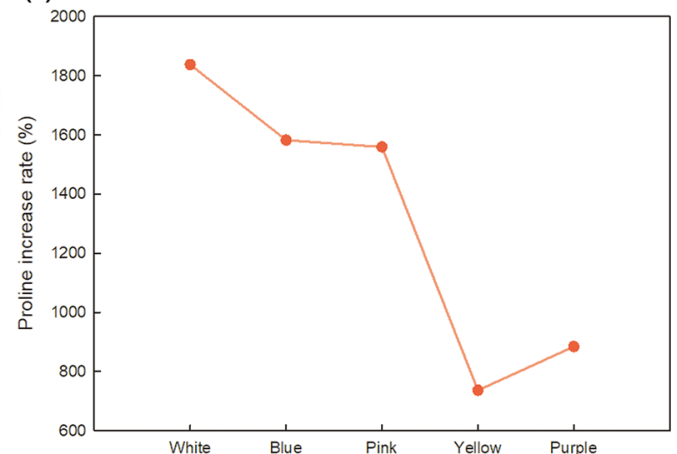

(h)

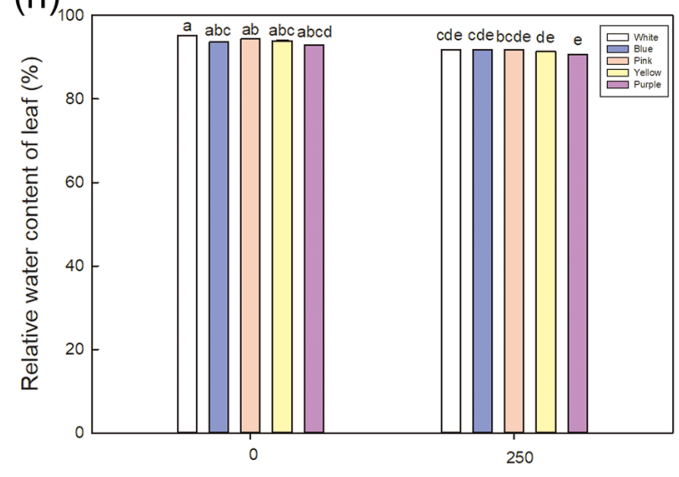

$\mathrm{NaCl}$ concentration $(\mathrm{mmol} / \mathrm{L})$

Figure 6. Effect of $\mathrm{NaCl}$ stress on MDA, soluble sugars, proline contents, $\mathrm{H}_{2} \mathrm{O}_{2}$ and relative water content in the leaves of five varieties of Limonium sinuatum. Contents of MDA (a), soluble sugars (c), proline (e), $\mathrm{H}_{2} \mathrm{O}_{2}$ (g) and relative water content $(\mathbf{h})$ of leaves under control and $\mathrm{NaCl}$ treatment in different varieties. The data are means \pm SD of five replicates. Different letters indicate significant differences between two groups at $P=0.05$ using Duncan's test with SPSS. The increase rate of MDA (b), soluble sugars (d) and proline (f) are calculated using (value under $\mathrm{NaCl}$ treatment-value under control)/value under control $\times 100 \%$. 

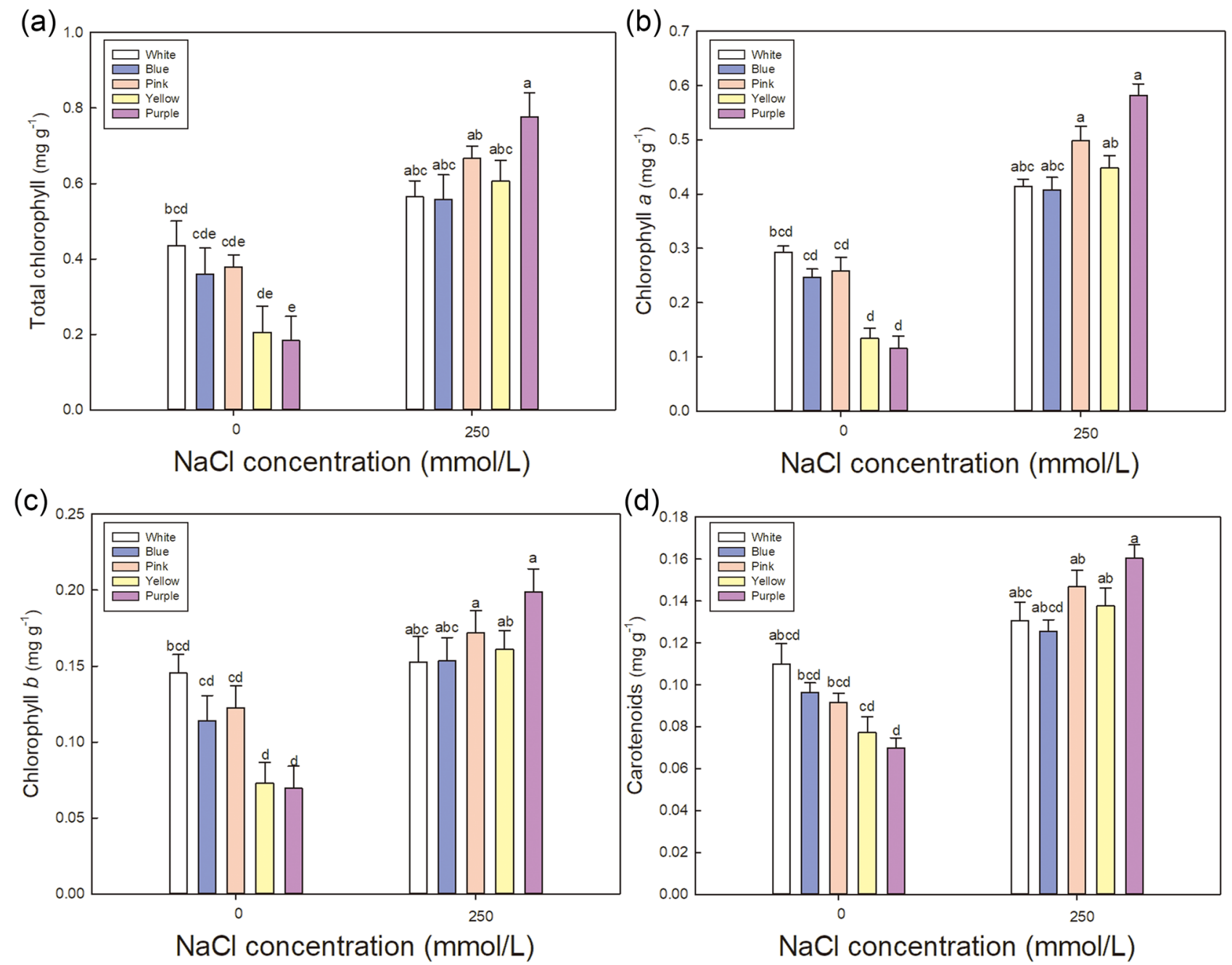

Figure 7. Effect of $\mathrm{NaCl}$ treatment on chlorophyll contents in the leaves of five varieties of Limonium sinuatum. (a-d) Total chlorophyll, chlorophyll $a$, chlorophyll $b$, and carotenoid contents under control and $\mathrm{NaCl}$ treatment. The data are means \pm SD of five replicates. Different letters indicate significant differences between two groups at $P=0.05$ using Duncan's test with SPSS.

potential, photosynthetic rate, and salt gland density under $250 \mathrm{mmol} / \mathrm{L} \mathrm{NaCl}$ (salt-tolerance threshold) treatment explained why Pink has the greatest salt tolerance. Moreover, analysis of plants grown in the field (Fig. 10) confirmed the superior salt resistance of Pink. Pink is recommended as the optimal varieties for extensive planting and greening in saline soil, followed by Yellow.

Plant biomass is an important indicator of salt tolerance ${ }^{43}$ : the greater the increase in biomass under salt stress, the higher the salt tolerance. As shown in Fig. 4, Pink showed the minimal reduction under $250 \mathrm{mmol} / \mathrm{L} \mathrm{NaCl}$ treatment, and photosynthetic efficiency of Pink was also the highest among five varieties (Fig. 8), indicating that Pink suffered the least damage under saline condition. The three basic components of salt stress are usually considered as ionic toxicity, osmotic stress and oxidative stress ${ }^{49}$.

How Pink cope with high ionic toxicity? On the one hand, under salt stress, $\mathrm{Na}^{+}$content increases, which affects the absorption of $\mathrm{K}^{+}$and $\mathrm{Ca}^{2+} . \mathrm{K}^{+}$plays an important role in the osmotic regulation of cells ${ }^{50}$. $\mathrm{Ca}^{2+}$ regulates the ionic balance and reduces the absorption of $\mathrm{Na}^{+51}$. In salt-tolerant plants, $\mathrm{K}^{+}$efflux is significantly inhibited under salt stress to maintain high intracellular $\mathrm{K}^{+} / \mathrm{Na}^{+}$levels, thereby reducing the damage from salt stress $^{52}$. After salt treatment, the Pink variety had the relatively low $\mathrm{Na}^{+}$and $\mathrm{Cl}^{-}$contents among the five varieties, whereas $\mathrm{K}^{+}$and $\mathrm{Ca}^{2+}$ showed the opposite trend. Therefore, Pink regulates ionic balance under salt stress, maintaining high $\mathrm{K}^{+} / \mathrm{Na}^{+}$levels, thus showing strong salt tolerance. On the other hand, salt gland is the typical and specific epidermal structure of recetohalophytes ${ }^{53}$, which can excrete the excessive $\mathrm{Na}^{+}$out of the plants to avoid damage ${ }^{54}$. The most salt gland was induced in Pink under salt treatment (Fig. 9), so it is speculated that $\mathrm{Na}^{+}$can be effectively transferred out of the cell to further avoid ionic toxicity.

$\mathrm{NaCl}$ can induce the physiological drought due to the osmotic stress. Compatible media was always generated to deal with the osmotic stress, such as proline and soluble sugars. Proline is an important compatible solute in plant cells that protects enzymes from inactivation by $\mathrm{NaCl}$ and reduces the osmotic potential in the cells $\mathrm{s}^{55}$, thereby helping plants resist external osmotic stress and tolerate adverse environments ${ }^{29}$. Sugar content under stress condition is intricately associated with carbohydrate content of plant ${ }^{25}$. Though not always the highest 

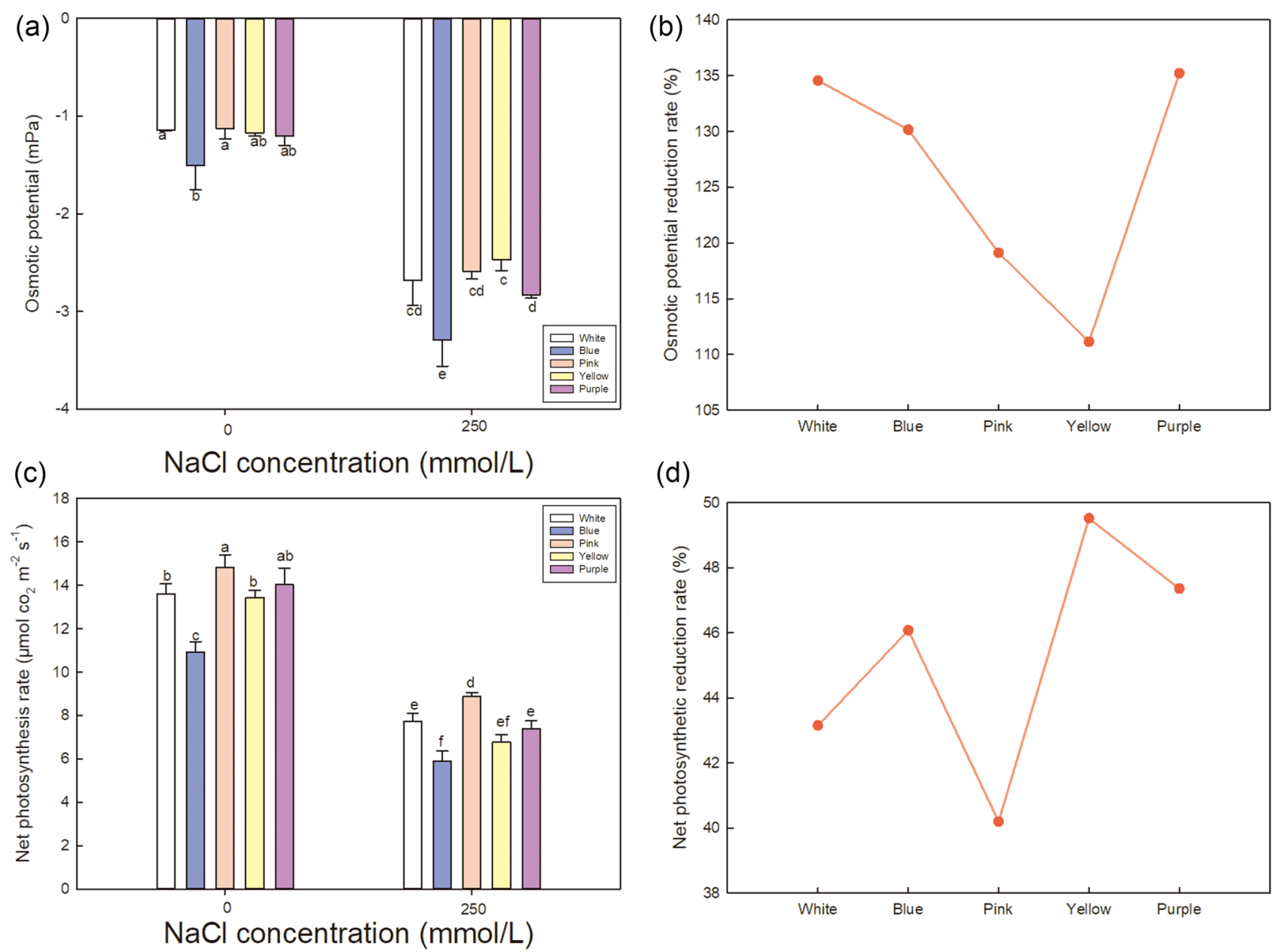

(d)

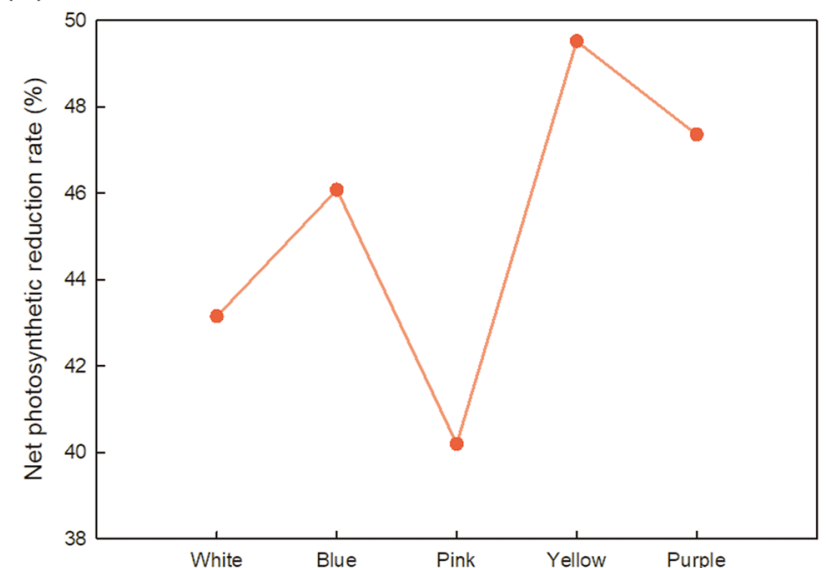

Figure 8. Effect of $\mathrm{NaCl}$ stress on the osmotic potential and net photosynthetic rate in the leaves of five varieties of Limonium sinuatum. (a, c) Osmotic potential and net photosynthetic rate under control and $\mathrm{NaCl}$ treatment. The data are means \pm SD of five replicates. Different letters indicate significant differences between two groups at $P=0.05$ using Duncan's with SPSS. (b, d) The reduction rate of osmotic potential and net photosynthetic rate under $\mathrm{NaCl}$ treatment. The reduction rate was calculated as (the value under control-the value under $\mathrm{NaCl}$ treatment)/the value under control $\times 100 \%$.

(a)

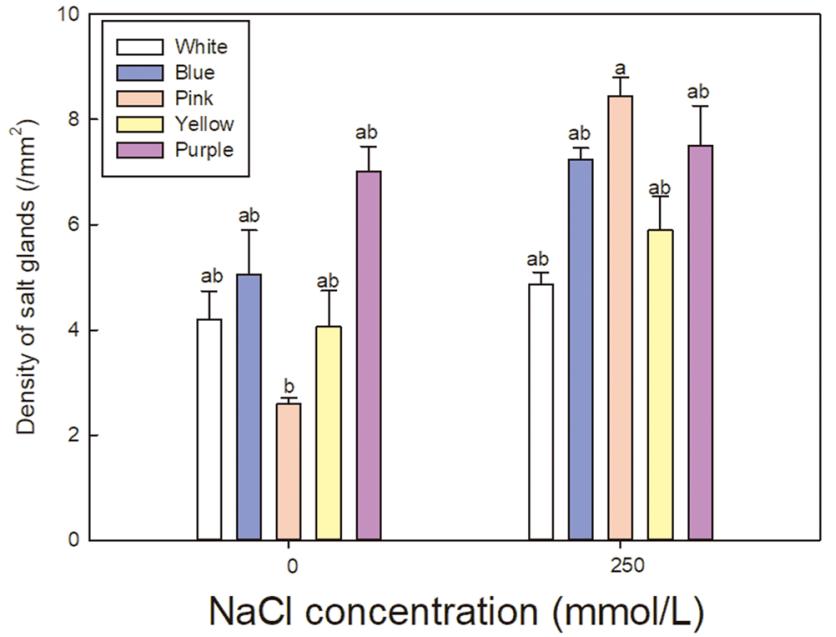

(b)

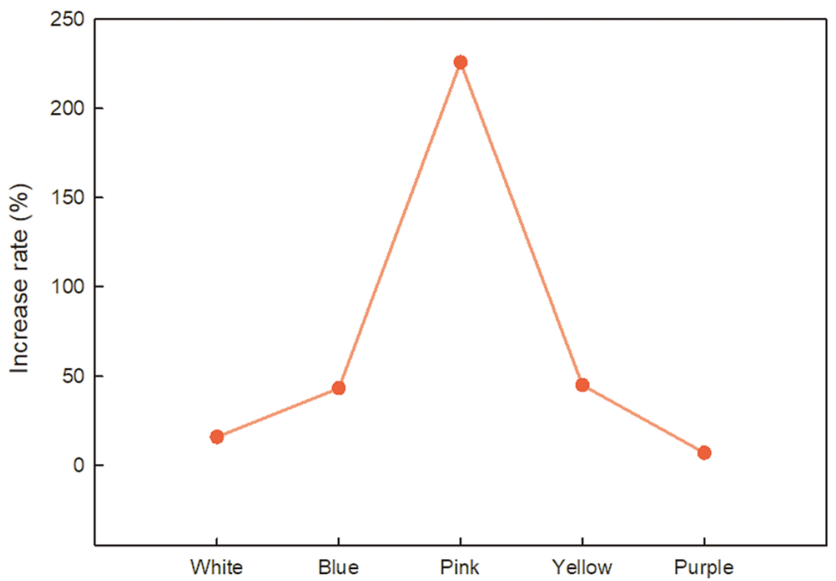

Figure 9. Effect of $\mathrm{NaCl}$ stress on salt gland density in the leaves of five varieties of Limonium sinuatum. (a) The data are means \pm SD of five replicates. Different letters indicate significant differences between two groups at $P=0.05$ using Duncan's with SPSS. (b) The increase rate of salt gland density was calculated using (value under $\mathrm{NaCl}$ treatment-value under control)/value under control $\times 100 \%$. 

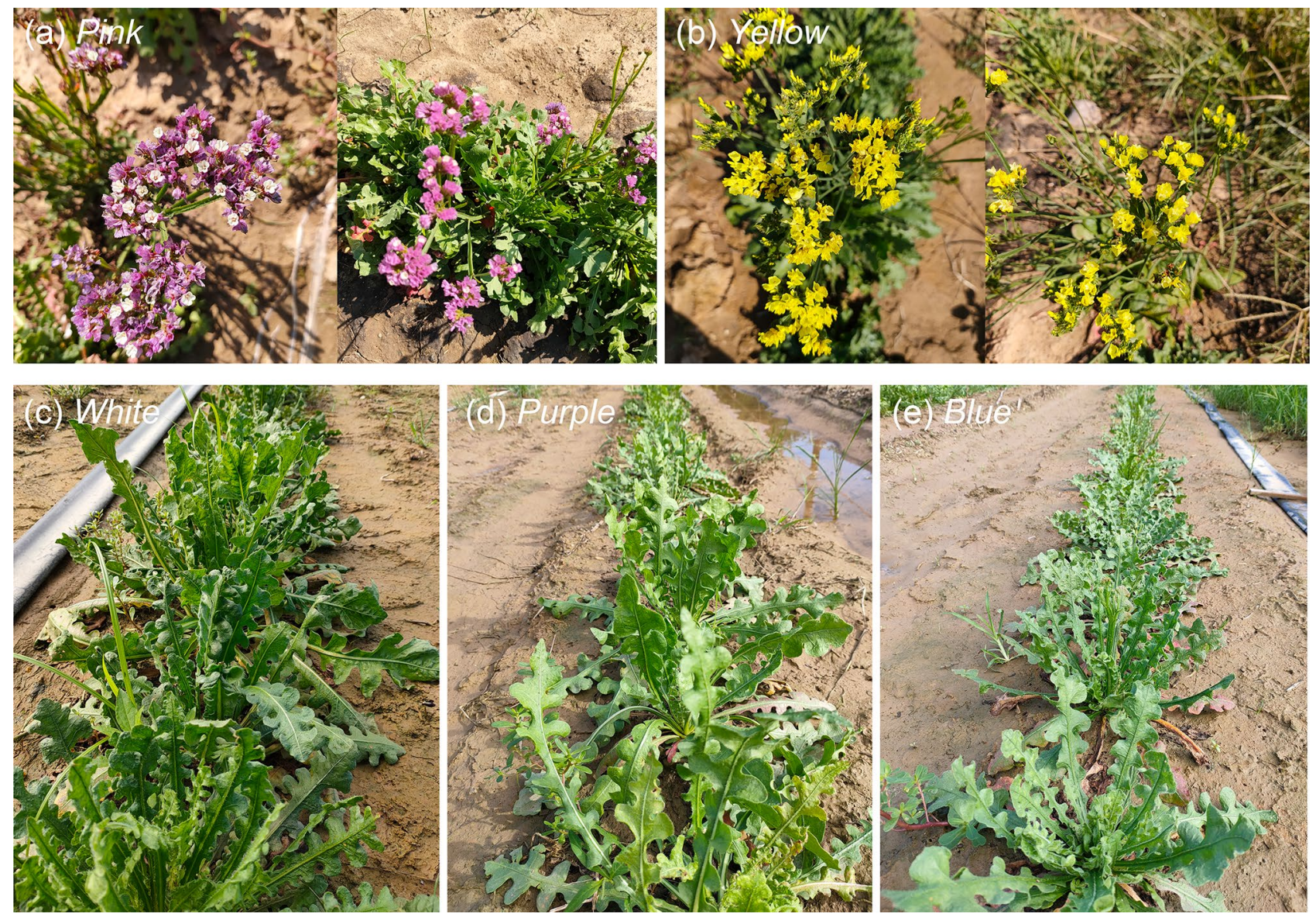

Figure 10. Growth of five varieties of Limonium sinuatum in saline soil.

\begin{tabular}{|c|c|c|c|c|c|c|c|c|c|c|c|c|c|c|c|c|c|}
\hline & Mean & Std. D & FW & DW & $\mathrm{Na}$ & $\mathbf{K}$ & $\mathrm{Ca}$ & $\mathrm{Cl}$ & MDA & Sugar & Proline & $\mathrm{H}_{2} \mathrm{O}_{2}$ & RWC & Chl & Os & Pr & SG \\
\hline FW & 4.0040 & 1.55376 & 1.000 & & & & & & & & & & & & & & \\
\hline DW & 0.3427 & 0.14626 & $0.955^{* *}$ & 1.000 & & & & & & & & & & & & & \\
\hline $\mathrm{Na}$ & 0.4891 & 0.14593 & -0.030 & 0.011 & 1.000 & & & & & & & & & & & & \\
\hline $\mathrm{K}$ & 0.3658 & 0.10977 & 0.444 & 0.386 & $0.579^{*}$ & 1.000 & & & & & & & & & & & \\
\hline $\mathrm{Ca}$ & 0.3192 & 0.05828 & -0.096 & 0.029 & -0.327 & -0.390 & 1.000 & & & & & & & & & & \\
\hline $\mathrm{Cl}$ & 0.0116 & 0.00171 & 0.120 & 0.207 & -0.209 & -0.303 & 0.452 & 1.000 & & & & & & & & & \\
\hline MDA & 0.0202 & 0.00521 & -0.246 & -0.292 & $0.587^{\star}$ & 0.330 & 0.046 & -0.046 & 1.000 & & & & & & & & \\
\hline Sugar & 0.8329 & 0.15517 & 0.349 & 0.365 & 0.193 & 0.006 & -0.265 & -0.226 & -0.012 & 1.000 & & & & & & & \\
\hline Proline & 13.9340 & 4.86710 & $-0.584^{*}$ & -0.445 & -0.431 & $\begin{array}{c}- \\
0.703^{* *} \\
\end{array}$ & $0.610^{*}$ & 0.315 & 0.038 & -0.273 & 1.000 & & & & & & \\
\hline $\mathrm{H}_{2} \mathrm{O}_{2}$ & 22.8932 & 11.46676 & 0.003 & -0.004 & $0.654^{\star \star}$ & $0.791^{* *}$ & -0.437 & -0.497 & 0.418 & 0.059 & -0.384 & 1.000 & & & & & \\
\hline RWC & 0.9145 & 0.01192 & -0.029 & -0.312 & -0.168 & 0.020 & -0.282 & -0.134 & 0.316 & -0.160 & -0.209 & -0.104 & 1.000 & & & & \\
\hline $\mathrm{Chl}$ & 0.6344 & 0.14499 & 0.316 & 0.431 & 0.069 & -0.001 & -0.086 & 0.126 & 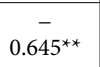 & 0.200 & -0.230 & -0.031 & $\begin{array}{c}- \\
0.547^{*}\end{array}$ & 1.000 & & & \\
\hline Os & -2.7737 & 0.34859 & -0.488 & -0.402 & 0.119 & -0.051 & -0.123 & -0.269 & 0.201 & -0.041 & 0.406 & 0.392 & -0.180 & -0.224 & 1.000 & & \\
\hline $\operatorname{Pr}$ & 7.3313 & 1.09242 & $0.674^{* *}$ & $0.591^{\star}$ & -0.092 & 0.447 & -0.223 & -0.101 & -0.332 & 0.243 & $\overline{-}$ & 0.049 & 0.023 & 0.179 & $\begin{array}{c}- \\
0.677^{* *}\end{array}$ & 1.000 & \\
\hline SG & 6.7918 & 2.46219 & -0.094 & -0.084 & -0.169 & -0.304 & 0.393 & 0.224 & -0.330 & -0.456 & -0.004 & -0.496 & -0.059 & 0.162 & $-0.570^{*}$ & \begin{tabular}{|l}
0.147 \\
\end{tabular} & 1.000 \\
\hline
\end{tabular}

Table 1. Correlation analysis between fresh weight (FW) and other 14 indicators including dry weight (DW), $\mathrm{Na}^{+}(\mathrm{Na}), \mathrm{K}^{+}(\mathrm{K}), \mathrm{Ca}^{2+}(\mathrm{Ca}), \mathrm{Cl}^{-}(\mathrm{Cl}), \mathrm{MDA}$, soluble sugars (Sugar), proline (Proline), hydrogen peroxide $\left(\mathrm{H}_{2} \mathrm{O}_{2}\right)$, relative water content (RWC) and chlorophyll contents (Chl), osmotic potential (Os), photosynthetic rate $(\mathrm{Pr})$, and salt gland density (SG) using Pearson correlation analysis. ${ }^{\star *}$ Correlation is significant at the 0.01 level (2-tailed). ${ }^{*}$ Correlation is significant at the 0.05 level (2-tailed). 
accumulation in proline and soluble sugars, Pink keep the relatively high level of osmotic adjustment substance to reduce the osmotic potential, which allowed the plant to re-absorb water from the $\mathrm{NaCl}$ solution to maintain normal growth.

Oxidative stress is inevitable induced by salt stress due to the generation of superoxide, with the typical representative $\mathrm{H}_{2} \mathrm{O}_{2}{ }^{56}$. Pink suffered the smallest oxidative stress under salt treatment and is more suitable for saline environment. MDA content can reflect the degree of membrane damage and the effects of stress on plants ${ }^{57}$. The least accumulation of MDA also insist the opinion that Pink suffered less oxidative stress.

Given that 16 physiological indicators were measured under salt treatment in addition to DW and FW, which one is most closely related to biomass? Correlation analysis was performed between FW and the other 14 indicators. As shown in Table 1, photosynthetic rate showed the strongest positive correlation with salt resistance in L. sinuatum.

Together, the results of our experiments show that the Pink variety has the strongest salt tolerance. Based on these results, the level of salt tolerance of the five varieties of L. sinuatum from high to low is Pink, Yellow, Purple, White, and Blue. Further analysis of the performance of these varieties in saline soil also validate the results of these preliminary experiments. Nonetheless, our findings provide a theoretical basis for the cultivation of $L$. sinuatum in saline-alkali areas, which could be widely planted to facilitate the greening and transformation of saline soils.

Received: 3 February 2021; Accepted: 5 July 2021

Published online: 15 July 2021

\section{References}

1. Lledó, M. D. et al. Endemism and evolution in Macaronesian and Mediterranean Limonium taxa. In The Biology of island Floras, 325-337 (2011).

2. Caperta, A. D., Róis, A. S., Teixeira, G., Garcia-Caparros, P. \& Flowers, T. J. Secretory structures in plants: Lessons from the Plumbaginaceae on their origin, evolution and roles in stress tolerance. Plant Cell Environ. 43, 2912-2931 (2020).

3. González-Orenga, S., Grigore, M. N., Boscaiu, M. \& Vicente, O. Constitutive and induced salt tolerance mechanisms and potential uses of Limonium Mill. species. Agronomy 11, 413 (2021).

4. Grieve, C. et al. Productivity and mineral nutrition of Limonium species irrigated with saline wastewaters. HortScience 40, 654-658 (2005)

5. Akat, H., Saracoglu, O. \& Cakar, H. Yield response of Limonium sinuatum cultivars under salinity stress. J. Environ. Biol. 41, 302-309 (2020).

6. Sheikh-Assadi, M., Khandan-Mirkohi, A., Alemardan, A. \& Moreno-Jiménez, E. Mycorrhizal Limonium sinuatum (L.) mill. enhances accumulation of lead and cadmium. Int. J. Phytoremed. 17, 556-562 (2015).

7. Ibrahim, H. E., El-Fadaly, H. \& El-Naggar, A. Study on the response of Statice plants (Limonium sinuatum, L.) to humic acid application. Alex. Sci. Exchange J. 37, 515-528 (2016).

8. Yan, W., Xiao, Y. J., Lin, Y. \& Chen, B. H. Study of Limonium sinense polyphenols inducing apoptosis in HL-60 human leukemia cells. J. Fujian Normal Univ. (Natural Science Edition) 02, 119-124 (2014).

9. Zhang, S. et al. Salinity influences Cd accumulation and distribution characteristics in two contrasting halophytes, Suaeda glauca and Limonium aureum. Ecotoxicol. Environ. Saf. 191, 110230 (2020).

10. Shrivastava, P. \& Kumar, R. Soil salinity: A serious environmental issue and plant growth promoting bacteria as one of the tools for its alleviation. Saudi J. Biol. Sci. 22, 123-131 (2015).

11. Ashraf, M., Akram, N., Arteca, R. N. \& Foolad, M. R. The physiological, biochemical and molecular roles of brassinosteroids and salicylic acid in plant processes and salt tolerance. Crit. Rev. Plant Sci. 29, 162-190 (2010).

12. Agami, R. Applications of ascorbic acid or proline increase resistance to salt stress in barley seedlings. Biol. Plant. 58, 341-347 (2014).

13. Amini, F. \& Ehsanpour, A. A. Soluble proteins, proline, carbohydrates and $\mathrm{Na}^{+} / \mathrm{K}^{+}$changes in two tomato (Lycopersicon esculentum Mill.) cultivars under in vitro salt stress. Am. J. Biochem. Biotechnol. 1, 204-208 (2005).

14. Parvaiz, A. \& Satyawati, S. Salt stress and phyto-biochemical responses of plants-a review. Plant Soil Environ. 54, 89 (2008).

15. Aslamsup, R., Bostansup, N., Mariasup, M. \& Safdar, W. A critical review on halophytes: Salt tolerant plants. J. Med. Plants Res. 5, 7108-7118 (2011).

16. Yuan, F., Lyu, M. J. A., Leng, B. Y., Zhu, X. G. \& Wang, B. S. The transcriptome of NaCl-treated Limonium bicolor leaves reveals the genes controlling salt secretion of salt gland. Plant Mol. Biol. 91, 241-256 (2016).

17. Yang, X., Dong, M. \& Huang, Z. Role of mucilage in the germination of Artemisia sphaerocephala (Asteraceae) achenes exposed to osmotic stress and salinity. Plant Physiol. Biochem. 48,131-135 (2010).

18. Yuan, F., Guo, J., Shabala, S. \& Wang, B. Reproductive physiology of halophytes: Current standing. Front. Plant Sci. 9, 1954 (2019).

19. Feng, Z. T. et al. $\mathrm{K}^{+}$accumulation in the cytoplasm and nucleus of the salt gland cells of Limonium bicolor accompanies increased rates of salt secretion under $\mathrm{NaCl}$ treatment using NanoSIMS. Plant Sci. 238, 286-296 (2015).

20. Yuan, F. et al. Comparative transcriptome analysis of developmental stages of the Limonium bicolor leaf generates insights into salt gland differentiation. Plant Cell Environ. 38, 1637-1657 (2015).

21. Mi, P., Yuan, F., Guo, J., Han, G. \& Wang, B. Salt glands play a pivotal role in the salt resistance of four recretohalophyte Limonium Mill. species. Plant Biol https://doi.org/10.1111/plb.13284 (2021).

22. Lu, C. et al. The SNARE protein LbSYP61 participates in salt secretion in Limonium bicolor. Environ. Exper. Bot. 176, 104076 (2020).

23. Huang, W. et al. Leaf fresh weight versus dry weight: Which is better for describing the scaling relationship between leaf biomass and leaf area for broad-leaved plants?. Forests 10, 256 (2019).

24. Wang, D., Yuan, F., Wang, B. \& Chen, M. Response of plant biofuel hybrid Pennisetum to $\mathrm{NaCl}$ stress and its salinity threshold. Chin. J. Plant Ecol. 36, 572-577 (2012).

25. Rahman, M. M. et al. Acetic acid: A cost-effective agent for mitigation of seawater-induced salt toxicity in mung bean. Sci. Rep. 9, $1-15(2019)$.

26. Roger, R. \& Manuel, J. Handbook of Plant Ecophysiology Techniques. Gas Exchange Techniques in Photosynthesis and Respiration Infrared Gas Analyser 113-139. (2003).

27. Higinbotham, N., Etherton, B. \& Foster, R. Mineral ion contents and cell transmembrane electropotentials of pea and oat seedling tissue. Plant Physiol. 42, 37-46 (1967). 
28. Wang, Y. F., Tseng, Y. C., Yan, J. J., Hiroi, J. \& Hwang, P. P. Role of SLC12A10. 2, a Na-Cl cotransporter-like protein, in a Cl uptake mechanism in zebrafish (Danio rerio). Am. J. Physiol. Regul. Integr. Comp. Physiol. 319, R82-R86 (2009).

29. Demiral, T. \& Türkan, I. Comparative lipid peroxidation, antioxidant defense systems and proline content in roots of two rice cultivars differing in salt tolerance. Environ. Exp. Bot. 53, 247-257 (2005).

30. Tomlinson, A., McCann, L. C. \& Pearce, E. I. Comparison of human tear film osmolarity measured by electrical impedance and freezing point depression techniques. Cornea 29, 1036-1041 (2010).

31. HongBo, S., ZongSuo, L. \& MingAn, S. Changes of anti-oxidative enzymes and MDA content under soil water deficits among 10 wheat (Triticum aestivum L.) genotypes at maturation stage. Colloids Surfaces B Biointerfaces 45, 7-13 (2005).

32. Vergara, R., Parada, F., Rubio, S. \& Pérez, F. J. Hypoxia induces $\mathrm{H}_{2} \mathrm{O}_{2}$ production and activates antioxidant defence system in grapevine buds through mediation of $\mathrm{H}_{2} \mathrm{O}_{2}$ and ethylene. J. Exp. Bot. 63, 4123-4131 (2012).

33. Prado, F. E., Boero, C., Gallardo, M. R. A. \& González, J. A. Effect of $\mathrm{NaCl}$ on growth germination and soluble sugars content in Chenopodium quinoa Willd. seeds. Bot. Bull. Acad. Sinica 41, 27-34 (2000).

34. Maxwell, K. \& Johnson, G. N. Chlorophyll fluorescence-a practical guide. J. Exp. Bot. 51, 659-668 (2000).

35. Wang, W. J. et al. Effect of collar insertion on soil respiration in a larch forest measured with a LI-6400 soil $\mathrm{CO}_{2}$ flux system. J. For. Res. 10, 57-60 (2005).

36. Zhang, X., Zhang, Y. \& Zhoub, Y. Measuring and modelling photosynthetically active radiation in Tibet Plateau during AprilOctober. Agric. For. Meteorol. 102, 207-212 (2000).

37. Yuan, F., Chen, M., Leng, B. \& Wang, B. An efficient autofluorescence method for screening Limonium bicolor mutants for abnormal salt gland density and salt secretion. S. Afr. J. Bot. 88, 110-117 (2013).

38. Ding, F., Chen, M., Sui, N. \& Wang, B. S. Ca ${ }^{2+}$ significantly enhanced development and salt-secretion rate of salt glands of Limonium bicolor under $\mathrm{NaCl}$ treatment. S. Afr. J. Bot. 76, 95-101 (2010).

39. Lieth, H., Sucre, M. G. \& Herzog, B. Tasks for vegetation sciences. In Mangroves and Halophytes: Restoration and Utilisation, Volume 43. Studies on halophytes and salinity problems in Mediterranean agriculture. 25-30 (2008).

40. McKenna, M. J., Bangsbo, J. \& Renaud, J. M. Muscle $\mathrm{K}^{+}, \mathrm{Na}^{+}$, and $\mathrm{Cl}^{-}$disturbances and $\mathrm{Na}^{+}-\mathrm{K}^{+}$pump inactivation: Implications for fatigue. J. Appl. Physiol. 104, 288-295 (2008).

41. Gomes, F. P., Oliva, M. A., Mielke, M. S., Almeida, A. A. F. \& Aquino, L. A. Osmotic adjustment, proline accumulation and cell membrane stability in leaves of Cocos nucifera submitted to drought stress. Sci. Hortic. 126, 379-384 (2010).

42. Monreal, J. et al. Proline content of sugar beet storage roots: Response to water deficit and nitrogen fertilization at field conditions. Environ. Exp. Bot. 60, 257-267 (2007).

43. Agarwal, R., Alborzi, P., Satyan, S. \& Light, R. P. Dry-weight reduction in hypertensive hemodialysis patients (DRIP) a randomized, controlled trial. Hypertension 53, 500-507 (2009).

44. Schützendübel, A., Nikolova, P., Rudolf, C. \& Polle, A. Cadmium and $\mathrm{H}_{2} \mathrm{O}_{2}$-induced oxidative stress in Populus $\times$ canescens roots. Plant Physiol. Biochem. 40, 577-584 (2002).

45. Ma, C. C., Li, Q. F., Gao, Y. B. \& Xin, T. R. Effects of silicon application on drought resistance of cucumber plants. Soil Sci. Plant Nutr. 50, 623-632 (2004).

46. Buttery, B. \& Buzzell, R. The relationship between chlorophyll content and rate of photosynthesis in soybeans. Can. J. Plant Sci. 57, 1-5 (1977).

47. Yuan, F., Leng, B. \& Wang, B. Progress in studying salt secretion from the salt glands in recretohalophytes: how do plants secrete salt?. Front. Plant Sci. 7, 977 (2016).

48. Huari, W. N. \& Mera, A. Erratum: Nauray Huari, W. \& Galán de Mera, A. Anales del Jardín Botánico de Madrid 65(1): 73-95. (2008).

49. Yuan, F., Xu, Y., Leng, B. \& Wang, B. Beneficial effects of salt on halophyte growth: Morphology, cells, and genes. Open Life Sci. 14, $191-200$ (2019).

50. Sutherland, L., Cairney, J., Elmore, M., Booth, I. \& Higgins, C. Osmotic regulation of transcription: Induction of the proU betaine transport gene is dependent on accumulation of intracellular potassium. J. Bacteriol. 168, 805-814 (1986).

51. White, R. J. \& Reynolds, I. J. Mitochondria and $\mathrm{Na}^{+} / \mathrm{Ca}^{2+}$ exchange buffer glutamate-induced calcium loads in cultured cortical neurons. J. Neurosci. 15, 1318-1328 (1995).

52. Hniličková, H., Hnilička, F., Orsák, M. \& Hejnák, V. Effect of salt stress on growth, electrolyte leakage, $\mathrm{Na}^{+}$and $\mathrm{K}^{+}$content in selected plant species. Plant Soil Environ. 65, 90-96 (2019).

53. Yuan, F. et al. Comparative transcriptome analysis of developmental stages of the $L$ imonium bicolor leaf generates insights into salt gland differentiation. Plant Cell Environ. 38, 1637-1657 (2015).

54. Leng, B. et al. The lb23 mutant of recretohalophyte Limonium bicolor (Bag.) Kuntze with 20-, 24-, 28-and 32-cell salt glands shows elevated salt secretion. Flora 259, 151441 (2019).

55. Okuma, E., Soeda, K., Tada, M. \& Murata, Y. Exogenous proline mitigates the inhibition of growth of Nicotiana tabacum cultured cells under saline conditions. Soil Sci. Plant Nutr. 46, 257-263 (2000).

56. Cho, U. H. \& Seo, N. H. Oxidative stress in Arabidopsis thaliana exposed to cadmium is due to hydrogen peroxide accumulation. Plant Sci. 168, 113-120 (2005).

57. Campos, P. S., nia Quartin, V., chicho Ramalho, J. \& Nunes, M. A. Electrolyte leakage and lipid degradation account for cold sensitivity in leaves of Coffea sp. plants. J. Plant Physiol. 160, 283-292 (2003).

\section{Acknowledgements}

This work was supported by the NSFC (National Natural Science Research Foundation of China, project nos. 31600200; 31770288), and the Development Plan for Youth Innovation Team of Shandong Provincial (2019KJE012).

\section{Author contributions}

F.Y. designed the research; X.X. and Y.Z. performed the research; X.X. and P.M. analyzed the data; X.X. wrote the paper; F.Y. and B.W. revised the paper.

\section{Competing interests}

The authors declare no competing interests.

Additional information

Supplementary Information The online version contains supplementary material available at https://doi.org/ 10.1038/s41598-021-93974-3.

Correspondence and requests for materials should be addressed to B.W. or F.Y. 
Reprints and permissions information is available at www.nature.com/reprints.

Publisher's note Springer Nature remains neutral with regard to jurisdictional claims in published maps and institutional affiliations.

(c) (i) Open Access This article is licensed under a Creative Commons Attribution 4.0 International License, which permits use, sharing, adaptation, distribution and reproduction in any medium or format, as long as you give appropriate credit to the original author(s) and the source, provide a link to the Creative Commons licence, and indicate if changes were made. The images or other third party material in this article are included in the article's Creative Commons licence, unless indicated otherwise in a credit line to the material. If material is not included in the article's Creative Commons licence and your intended use is not permitted by statutory regulation or exceeds the permitted use, you will need to obtain permission directly from the copyright holder. To view a copy of this licence, visit http://creativecommons.org/licenses/by/4.0/.

(C) The Author(s) 2021 